\title{
A Retrospective Study of Oral Manifestations in Patients with Paracoccidioidomycosis
}

\author{
Marcelo Rodrigues AZENHA \\ Rubens CALIENTO \\ Luiz Guilherme BRENTEGANI \\ Suzie Aparecida de LACERDA \\ Department of Stomatology, Ribeirão Preto Dental School, \\ USP - University of São Paulo, Ribeirão Preto, SP, Brazil
}

\begin{abstract}
South American blastomycosis, paracoccidioidomycosis ( $\mathrm{Pb}$ mycosis) or Lutz disease is an endemically fungal infection in Latin America. It is caused by the dimorphic fungus Paracoccidioides brasiliensis and may cause oral mucosal lesions. The incidence of $\mathrm{Pb}$ mycosis oral lesions was evaluated in patients assisted at a Brazilian Dental School's Specialized Oral Diagnosis Service with special focus on the different clinical forms of these lesions, its location, patients' occupation, deleterious habits, and diagnosis methodology. Students' and professionals' initial diagnoses were compared with the definitive diagnosis. Lesions were detected 31 cases (18 patients). The results show that $88.8 \%$ of the patients were male with a mean age of 50 years and $39 \%$ work(ed) with activities related to agriculture. As much as $88.9 \%$ were smokers and $72.2 \%$ were alcohol users. Exfoliative cytology was performed in $66.6 \%$ of the patients. Oral mucosa (30\%), gingiva (16.6\%) and lips $16.6 \%$ were the most common sites of $\mathrm{Pb}$ mycosis oral lesions. Comparing the initial with the definitive diagnosis made by the professionals their accuracy was 33\% (6 out of 18 patients). Students' diagnosis was more accurate demonstrating $72.5 \%$ of initial correct diagnosis ( 13 out of 18$)$. Statistical analysis by ANOVA $(\alpha=0.05$, SPSS WIN) demonstrated a significant difference between the diagnosis of $\mathrm{Pb}$ mycosis made by students and professionals when considering initial diagnosis and final diagnosis (after histopathological analysis) $(\mathrm{p}=0.25)$. Incisional biopsy and exfoliate cytology are efficient for an early diagnosis of this disease in mouth. Students' training in diagnosis of oral pathologies to recognize lesions is urgent to improve public health.
\end{abstract}

Key Words: paracoccidioidomycosis, diagnosis, exfoliative cytology, oral lesions.

\section{INTRODUCTION}

South American blastomycosis, paracoccidioidomycosis ( $\mathrm{Pb}$ mycosis) or Lutz disease, a chronic granulomatous disease caused by the dimorphic fungus Paracoccidioidis brasiliensis is the most prevalent systemic mycosis on South America (Brazil, Argentina, Colombia, and Venezuela) that usually affects healthy, middle-aged adults, most of them men involved in rural activities. This disease causes cutaneous and/ or respiratory tract mucosal lesions ranging from oral ulcerations, extensive laryngeal lesions and diffuse interstitial pulmonary involvement $(1,2)$.

$\mathrm{Pb}$ mycosis presents a marked tendency to dissemination for any organ or system, such as lungs, lymph nodes, mucosa of the upper respiratory and digestive tracts, skin, adrenal glands, bones and joints, central nervous system, eyes, urogenital tract, and thyroid.
Due to such behavior, polymorphic manifestations are frequently observed, which impairs the establishment of a diagnosis by the clinical aspects. Thus, $\mathrm{Pb}$ mycosis is not always suspected and sometimes patients can be misdiagnosed, mainly in cases of females and younger individuals (3). However, the oral lesions are suggestive of the disease and of easy diagnosis.

Healthy subjects living in endemic areas may be infected by inhalation of propagules of fungus and develop one of the two clinical forms: (i) acute or subacute form, with severe involvement of the mononuclear phagocyte system; or (ii) the chronic form, with insidious evolution and involvement of one or more organs. Oral lesion morphology is variable, but the most common pattern is an infiltrative lesion with a fine granular surface which eventually resembles a mulberry (moriform stomatitis) or ulcerative lesions with infiltrated borders. Small lesions $(0.5 \mathrm{~cm})$ or 
extensive plaques may be seen, and different regions are frequently involved. Sometimes, the oral lesions are painful, especially with ingestion of hot or salty food (4).

Diagnosis of $\mathrm{Pb}$ mycosis is confirmed by the observation of multibudding and birefringent yeast cells by direct microscopic examination of biologic fluids (sputum, bronco-pulmonary secretions) or histopathological examination of skin and mucosal biopsies, and also by isolation of the fungus in cultures. Direct microscopic examination is definitive and the gold standard method to identify the fungus in lesions. Culture usually requires a long time, is less sensitive than direct examination and has a high rate of negative results, especially if the samples are contaminated or in small amount. Paracoccidioidal mucosa and lymph node lesions must be included in the differential diagnosis of other granulomatous infection diseases. Patients with mucocutaneous leishmaniosis can be differentiated by the presence of nasal lesions. $\mathrm{Pb}$ mycosis should also be differentiated from cancers of the oral cavity, oropharynx and larynx, most commonly the result of squamous cell carcinoma and lymphoma (5).

The aim of this work was to evaluate the prevalence of $\mathrm{Pb}$ mycosis oral lesions in patients assisted at a public specialized oral diagnosis center, with special focus on the different clinical forms of these lesions, its location, patients' occupation, deleterious habits, and diagnosis methodology. Students' and professionals' initial diagnoses were compared with the definitive diagnosis.

\section{MATERIAL AND METHODS}

All patients of this study were referred to our Dental School's Specialized Oral Diagnosis Service between 2006 and 2010 with a suspect $\mathrm{Pb}$ mycosis diagnosis. Different characteristics were evaluated, including gender, age, medications in use, occupation, deleterious habits, affected oral region and pathological aspects, diagnosis technique, and treatment modalities. Students' and professionals' initial diagnoses were compared with the definitive diagnosis. The present work received ethical approval from the institutional Ethics Committee (Protocol \#0030.0.138.000-11).

The statistical analysis was undertaken with the discrepancies between final diagnosis ( $\mathrm{Pb}$ mycosis) and the initial diagnosis was done to verify if there was statistical difference between the diagnoses made by the professionals who referred the patients to our Center and those made by the undergraduate dental students who received the patients at our Center. The results were compared by ANOVA at 5\% significance level using the SPSS software (SPSS Inc., Chicago, IL, USA).

\section{RESULTS}

Review of the records of 18 patients with a definitive diagnosis of $\mathrm{Pb}$ mycosis revealed that 16 $(88.8 \%)$ were males and only $2(11.2 \%)$ were females, with age varying from 24 to 73 years (mean age $=50.22$ ). A total of 31 lesions were detected in 18 patients. Fourteen patients $(77.8 \%)$ were using some type of medication to treat other systemic conditions or to relieve pain/blazing caused by the oral lesion. Out of these, 2 were taking Itraconazole (patient \#1) and Bactrim (patient \#2) after previous evaluation at another specialized treatment center. Seven $(39 \%)$ patients work(ed) with activities related to agriculture.

Sixteen $(88.8 \%)$ patients were smokers, 13 $(72.2 \%)$ were alcohol users sporadically or routinely and $3(16.6 \%)$ used to put objects in mouth like sticks or to chew grass. Exfoliative cytology was performed in $12(66.6 \%)$ lesions and incisional surgery in $6(33.3 \%)$ of the patients.

Oral mucosa (9 lesions; 30\%), gingiva and lips ( 5 cases; $16.6 \%$ each) were the most common sites of $\mathrm{Pb}$ mycosis, followed by the palatal region (4 cases; $13.3 \%$ ), tongue ( 3 cases; $10 \%$ ), and floor of the mouth and tuber area ( 2 cases; $6.6 \%$ each) (Fig. 1).

$\mathrm{Pb}$ mycosis lesions presented different characteristics like a moriform aspect with bleeding points, infiltrative lesions with a fine granular surface which eventually resembles a mulberry (moriform stomatitis), or ulcerative lesions with infiltrated borders.

Comparing the initial with the definitive diagnosis made by the professionals their accuracy was 33\% (6 out of 18 patients). Eight (44.5\%) patients were referred without a diagnosis, $2(11.1 \%)$ had defined the lesion as squamous cell carcinoma, 1 (5.5\%) was referred with an initial diagnosis of leukoplakia, and 1 (5.5\%) as epithelial hyperplasia. Students' diagnosis was more accurate demonstrating $72.5 \%$ of initial correct diagnosis (13 out of 18$)$. In three patients $(16.5 \%)$, the initial diagnosis was squamous cell carcinoma. Another one $(5.5 \%)$ was initially diagnosed with candidiasis and in one (5.5\%) the diagnostic was inconclusive (Fig. 2). Statistical analysis demonstrated a significant difference between the diagnosis of $\mathrm{Pb}$ mycosis made by students 
and professionals when considering initial and final (after histopathological analysis) diagnostic ( $\mathrm{p}=0.25)$.

\section{DISCUSSION}

After inhalation, fungal organisms penetrate the respiratory tract and lodge in the lungs, producing a primary infection. From the lungs, the fungi invade other organs and spread, leading to granulomatous mucosal and skin lesions appearance, with the majority of the cases involving rural workers or residents of these areas (6). The involvement of 10 (33\%) of patients with activities related to agriculture found at this work is similar to other studies $(3,7,8)$. The different clinical forms of $\mathrm{Pb}$ mycosis often lead the patients to have a delayed diagnosis, making the treatment of its disease more complicate, diminishing patients' survival and quality of life. The differential diagnosis of $\mathrm{Pb}$ mycosis is

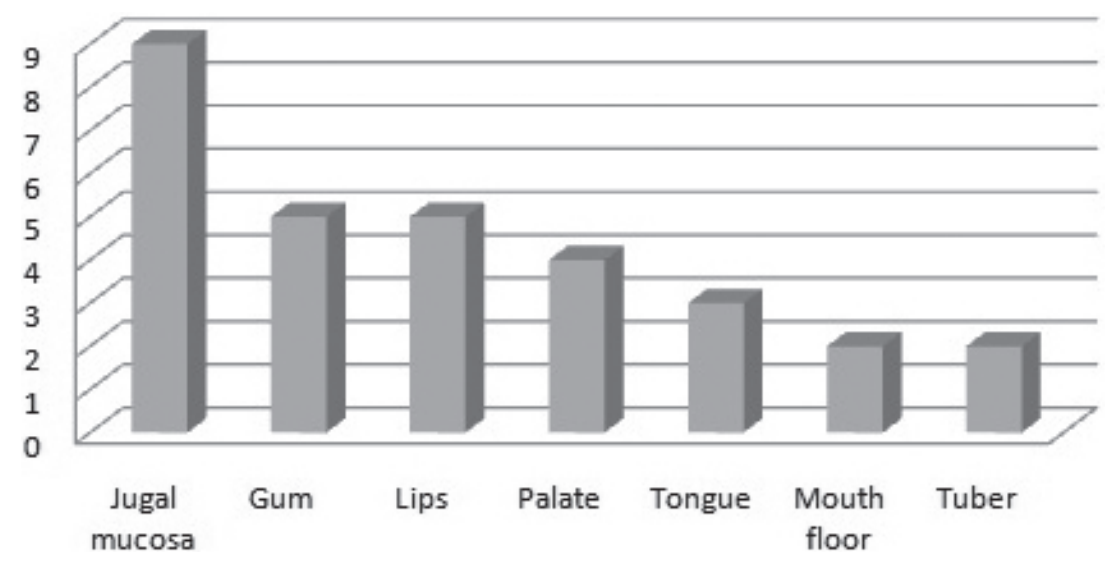

Figure 1. Location of $\mathrm{Pb}$ lesions in the oral cavity.

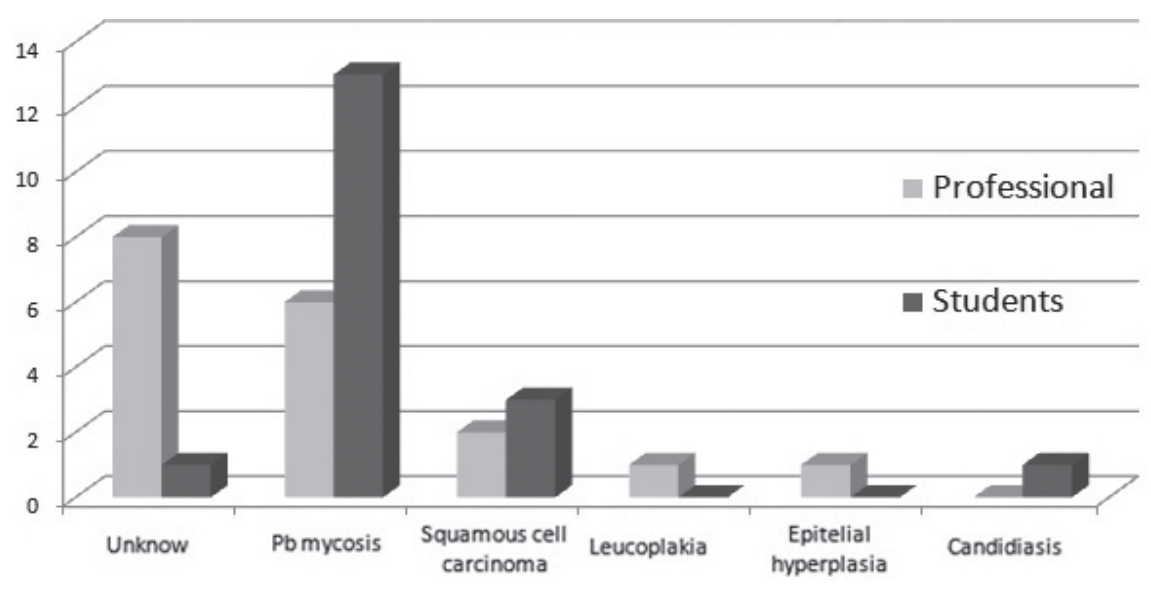

Figure 2. Professionals' and students' initial diagnosis. made observing some important signs such as localized or systemic adenopathy, presence of oral mucosa or skin lesions, and pulmonary involvement. Patients' general health can also be affected by some nonspecific systemic manifestations, including anemia, weight loss, headaches and fever (9). $\mathrm{Pb}$ mycosis may occur as a subclinical infection and, when clinically apparent, it may have some different characteristics such as acute or subacute and chronic stages. The acute or subacute form tends to be rapidly progressive and affects young individuals as moderate or severe. In both groups, mortality tends to be high if left untreated (10). The chronic form of $\mathrm{Pb}$ mycosis shows a male predominance, age between 30 and 60 years and it is the most common form of the disease. The male-to-female ratio is 19:1 due to a female hormone ( $\beta$-estradiol) that prevents the differentiation of the fungi to pathogenic form. The present results demonstrate similar findings to those of other studies (6).

The signs and symptoms of $\mathrm{Pb}$ mycosis include oral pain, drooling, unpleasant mouth odor, and difficult of mastication being diagnosed in different oral regions. When located in the gingiva or palate, the lesion may have a moriform characteristic aspect with bleeding points. Often there is periapical and periodontal involvement, which can cause spontaneous exfoliation of teeth. It is quite common the patient report disease manifesting after extraction of a periodontally compromised tooth. Differential diagnosis is done with cancer, tuberculosis, syphilis, Wegener granuloma, leishmaniasis and other mycoses, such as histoplasmosis and coccidiodomicose (3). Meneses-Garcia et al. (11) reported two cases of $\mathrm{Pb}$ mycosis mimicking squamous cell carcinoma, which highlights the importance of an adequate biopsy specimen not to avoid misdiagnosis. In general, granulomatous 
infections exhibit a pseudoepitheliomatous hyperplasia and this may lead to a mistaken diagnosis of cancer. Also, $\mathrm{Pb}$ mycosis oral lesions may present different characteristics, but the most common pattern is defined as infiltrative lesions with a fine granular surface, which occasionally resemble a mulberry (moriform stomatitis) or ulcerative lesions with infiltrated borders, but small lesions or extensive plaques may be seen. In this study, different forms of these lesions in oral cavity were seen and the definitive diagnosis was done by means of incisional or exfoliative biopsy.

When the definitive diagnosis was compared with the initial diagnosis made by the professionals who referred the patients to our Center or by the students who assisted the patients at our Center, it was verified that only $33.3 \%$ of the professionals made the correct diagnosis while $72.5 \%$ of correct diagnosis was made by the students before any biopsy technique. The professional who referred the patients to our Center work in public dental offices and are general dentists that are not familiarize to oral lesions. Differently from professionals, the students of our specialized Center are effectively involved in pathological oral diagnosis with constant practice, demonstrating the importance of routine practice to detect and indicate correct treatment. Garcia et al. (12) described a 41-year-old man with paracoccidioidomycosis of the larynx mimicking carcinoma. After staining with Grocott (13) method, the diagnosis of $\mathrm{Pb}$ mycosis was conclusive with no histopathological evidence of malignancy. Those authors concluded that $\mathrm{Pb}$ mycosis should be suspected in individuals who have lived in endemic areas and who present lesion similar to carcinoma.

The diagnostic methods of $\mathrm{Pb}$ mycosis can be exfoliative cytology or incisional biopsy, the first being a valid and useful examination due to simplicity, low cost, minimal side effects and its routine use in outpatients to diagnosis suspicious oral lesions (14). Another advantage of this examination is its use in patients with compromised immune system, where the intervention of an incisional biopsy, as it may seem simple, can bring a huge risk to patient's life. Traditionally, the procedure used for the diagnosis of the suspicious oral lesions of $\mathrm{Pb}$ mycosis is the incisional biopsy with subsequent histopathological analysis using staining methods specific to the fungus (15). For Grocott (13), impregnation by silver metanamine was found to be superior when used for diagnosis of fungal lesions, with this method being used after obtaining the smears by exfoliative cytology. As cited above, the preferencial method for diagnosis of $\mathrm{Pb}$ mycosis is the isolation of the fungus in culture and the positive identification of multibudding and birefringent yeast cells by direct examination of biologic fluids or biopsy specimens (16).

The treatment of $\mathrm{Pb}$ mycosis is done even with fluconazole, ketoconazole or itraconazole, drugs that cause a disturbance in fungal membrane permeability, inhibiting ergosterol synthesis. Fluconazole presents the best results, knowing that $80 \%$ of its dose is excreted in the urine and its absorption is not affected by food or acidity. Amphotericin B is a potentially nephrotoxic drug and it is no longer used as routine due to its capability of producing systemic effects. An important information is that dental interventions in patients with active lesions should not be performed unless the patient uses appropriate medications for at least 3 months uninterrupted in order to avoid the risk of fungus spread (17).

In conclusion, oral lesions were found in all patients with $\mathrm{Pb}$ mycosis, confirming their high stomatological incidence. It was also demonstrated the importance of specialized oral care professionals in a multidisciplinary team to achieve the best treatment outcome and follow up of patients affected by this disease.

\section{RESUMO}

Ablastomicose sul americana, paracoccidiodomicose ( $\mathrm{Pb}$ micose) ou doença de Lutzé uma infecção fúngica endêmica na América Latina. É causada pelo fungo dimórfico Paracoccidiodes brasiliensis, e pode causar lesões na mucosa oral. Nós avaliamos a incidência de lesões orais de $\mathrm{Pb}$ micose nos pacientes atendidos em um Centro Especializado em Diagnóstico Oral com foco principal nas diferentes formas clinicas das lesões, suas localidades, ocupação dos pacientes, hábitos deletérios e diagnóstico e metodologia, e foram detectados 31 casos (18 pacientes). Os resultados mostraram que $88,8 \%$ dos pacientes eram do sexo masculino com idade média de 50 anos de idade, e $39 \%$ trabalham, ou trabalhavam, com atividades relacionadas à agricultura. Observou-se que 88,9\% eram fumantes e 72,2\% ingeriam álcool. Citologia esfoliativa foi feita em $66,6 \%$. Mucosa jugal foi acometida em 30\%, gengiva, e lábios 16\% (cada um) foram os locais mais comuns de lesões orais da $\mathrm{Pb}$ micose. Comparando o diagnóstico inicial com o definitivo feito pelos profissionais, a acurácia foi de $33 \%$; o diagnóstico dos estudantes foi mais preciso demonstrando $72,5 \%$ do diagnóstico inicial correto com diferença estatística significante $(p=0,25)$ através do teste ANOVA do SPSS WIN com nível de significância de 5\%. Biópsia incisonal e citologia esfoliativa são eficientes para um diagnóstico precoce desta doença na boca; o treinamento dos estudantes em diagnóstico para reconhecer as patologias orais é urgente para melhorar a saúde pública. 


\section{REFERENCES}

1. Lopes Neto JM, Severo LM, Mendes RP, Weber SA. Sequelae lesions in the larynxes of patients with paracoccidioidomycosis. Braz J Otorhinolaryngol 2011;77:39-43.

2. Gomes E, Wingeter MA, Svidzinski TI. Clinical-radiological dissociation in lung manifestations of paracoccidioidomycosis. Rev Soc Bras Med Trop 2008;4:454-458.

3. Neville BW, Damm DD, Allen CM, Bouquot JE. Oral and maxillofacial pathology. Philadelphia: Saunders/Elsevier; 2009. 984 p.

4. Restrepo A, Tobón AM, Agudelo CA, Ochoa JE, Rosero DS, Osorio ML, et al.. Co-existence of integumentary lesions and lung X-ray abnormalities in patients with paracoccidioidomycosis (PCM). Am J Trop Med Hyg 2008;79:159-163.

5. Shikanai-Yasuda MA, Conceição YM, Kono A, Rivitti E, Campos AF, Campos SV. Neoplasia and paracoccidioidomycosis. Mycopathol 2008;165:303-312.

6. Caballero SS, Arenas R, Vega MME, Lopez JRM, Mosqueda TA. Paracoccidioidomycosis: report of a case treated with fluconazole. Med Oral 1998;3:91-95.

7. Verli FD, Marinho AS, Souza SC, Figueiredo MAS, Yurgel LS. Clinical-epidemiologic profile of paracoccidioidomycosis at the Stomatology Department of São Lucas Hospital, Pontifical Catholic University of Rio Grande do Sul. Rev Soc Bras Med Trop 2005;38:234-237.

8. Vieira EMM, Borsato-Galera B. Oral clinical manifestations of paracoccidioidomycosis. Rev Patol Trop 2006;35:23-30.

9. Quagliato-Júnior R, Grangeia AT, Massucio RA, De Capitani
EM, Rezende MS, Balthazar AB. Association between paracoccidioidomycosis and tuberculosis: reality and misdiagnosis. Braz J Pneumol 2007;33:295-300.

10. Brummer E, Castaneda E, Restrepo A. Paracoccidioidomycosis: an update. Clin Microbiol Rev 1993;6:89-117.

11. Meneses-Garcia A, Mosqueda-Taylor A, Luz RM, Rivera LMRG. Paracoccidioidomycosis: Report of 2 cases mimicking squamous cell carcinoma Oral Surg Oral Med Oral Pathol Oral Radiol Endod 2002;94:609-613.

12. Garcia I, Barbella R, Dickson S, Diaz S, Rodriguez-Morales AJ, Ravelo M, et al.. Paracoccidioidomycosis (South American blastomycosis) of the larynx mimicking carcinoma. Am J Med Sci 2008;335:149-150.

13. Grocott RG. A stain for fungi in tissue sections and smears: using Gomori's methenamine - silver nitrate technique. Am J Clin Pathol 1955;25:975-979.

14. Araújo MS, Sousa SCOM, Correia D. Evaluation of cytopathologic exam for diagnosis of oral chronic paracoccidioidomycosis. Rev Soc Bras Med Trop 2003;36:427-430.

15. Sposto MR, Mendes-Giannini MJ, Moraes RA, Branco FC, Scully C. Paracoccidioidomycosis manifesting as oral lesions: clinical, cytological investigation. J Oral Pathol Med 1994;23:85-87.

16. Gomes GM, Cisalpino PS, Taborda CP, Camargo ZP. PCR for diagnosis of paracoccidioidomycosis. J Clin Microbiol 2000;38:3478-3480.

17. Como JA, Dismukes WE. Oral azole drugs as systemic antifungal therapy. N Engl J Med 1994;330:263-272.

Received November 29, 2011 Accepted April 13, 2012 